\title{
Brand Personality Moderating Effect on Relationship between Website Quality and Online Trust: Malaysian Online Environment Context
}

\author{
Alireza Habibi ${ }^{1}$, Sahar Golkari Hagh ${ }^{1}$, Mehdi Hooshmand Bahabadi ${ }^{1}$, Sharareh Shahidi Hamedani ${ }^{1}$, Norjaya \\ Mohd Yasin ${ }^{1} \&$ Nor Asiah Omar ${ }^{2}$ \\ ${ }^{1}$ Graduate School of Business, Universiti Kebangsaan Malaysia, Malaysia \\ ${ }^{2}$ Faculty of Economics and Management, Universiti Kebangsaan Malaysia, Malaysia \\ Correspondence: Alireza Habibi, Graduate School of Business, Universiti Kebangsaan Malaysia, 43600 UKM, \\ Bangi, Selangor, Malaysia. E-mail: tajbluediamond@gmail.com
}

Received: January 6, 2014 Accepted: April 15, 2014 Online Published: May 30, 2014

doi:10.5539/ass.v10n11p210 URL: http://dx.doi.org/10.5539/ass.v10n11p210

\begin{abstract}
The objective of this paper is to examine whether the brand personality which includes two dimensions namely, (sincerity/trustworthiness) and (youthfulness/modernity), can moderate the relationship between website quality and online trust. This study considers the impact of the quality of website on online trust and the extent it encourages purchase intentions in the Malaysian context. The data for the study were collated from responses from a sample of 229 college students in Malaysia. The survey included questions on items that measured brand personality, web site quality, online trust and purchase intentions. The data was evaluated by applying multiple regression analysis to establish the relationship among variables.The findings indicate that both dimensions of brand personality, namely (sincerity/trustworthiness) and (youthfulness/modernity) are able to moderate the relationship between web site quality and online trust. However, the results suggest that the impact of (youthfulness/ modernity) is more significant compared to (sincerity/trustworthiness).It was evident that in the Malaysian context, it was imperative for an organization to present an updated and exciting website to attract more consumers to purchase online through its website. This study enhances and augments the existing pool of knowledge on websites with special emphasis on online transactions.. This study provides a better understanding on the perception of Malaysian customers towards web-based transactions. The findings also offer valuable information to the marketing and information managers of organizations with regard to online business transactions.
\end{abstract}

Keywords: brand personality, online environment, online trust

\section{Introduction}

In recent years, there has been an exponential increase in the number of internet users. According to data released by the World Bank, 61 out of 100 people in Malaysia had access to the internet (www.worldbank.org/indicator/IT.net.user) during the period between 2008 and 2012. This fact alone is sufficient to demonstrate the potential scope of e- business. Needless to say, it is obvious that Malaysia has an optimistic future for business expansions in the e-commerce sector. This observation is further strengthened by the findings of a survey by International Data Corporation (IDC) undertaken in 2007 which revealed that the total e-commerce expenditure in Malaysia for the year was USD \$22.3 billion and was forecasted to double in 2013.

It is widely accepted reality that websites have gained much prominence as gateways in promoting e-business and thus, expanding the e-commerce sector. In essence, websites resemble enhanced retail outlets due to their capability to touch base with customers throughout domestic and international markets in a most cost effective manner, permitting constant updates and driving innovations (Eroglu et al., 2001). Taking cognition of the crucial role of websites in fostering growth of e-commerce, the design of website features should be given due consideration as they are crucial in influencing consumer purchase intentions (Eroglu et al., 2001; Van der Heijden et al., 2003).

Furthermore, the website could be the dominant mode of communications between the online store and its customers (Chen \& Dhillon, 2003). It is noted that in the initial stages of design of online communications, even 
the appearance (e.g. color appeal) which is a measure of the dimensions of website quality, could be a significant determinant of website trust and satisfaction, and this varies across cultures. For example, the Germans have a penchant for blue color patterns, while the Canadians prefer grey color schemes more than the Germans or the Japanese. While the Japanese are impartial to websites with bright yellow tones, western communities such as Canadians and Germans dislike yellow color schemes as they prefer blue color formats (Cyr et al., 2010).

Prior studies to some extent have been successful in providing an understanding of the behavior of e-consumers in relation to website quality. However the preferences and responses of different races such as Chinese, Indians and Malays with different cultural outlook and diverse personalities, to the website quality have yet to be empirically examined (Law \& Cheung, 2006). In recent years, the impact of online cues on consumer purchase intention behavior, has increasingly become the focus of study by researchers (Harris \& Goode, 2010; Chang \& Wang, 2008, Wang et al., 2012). The brand has become a crucial prompt to influence consumers' online purchase intentions (Yoon, 2002; Rowley, 2004). It could be prevailed that brand personality increases brand usage (Sirgy, 1982), levels of trust, loyalty and engagement (Fournier, 1998), as the intention to purchase is often influenced by the perceived website quality and brand personality (Poddar et al., 2009). However, the literature review indicates that no study has been undertaken to examine empirically the moderating effect of brand personality on the relationship between website quality and trust.

This study delves on the aspect of trust as a psychological state of mind, which has been identified as a critical factor that impacts customers' decisions on online purchase considerations (Gefen, 2000; Chen \& Barnes, 2007). In exploring the motives in an online environment, intention theories such as the theory of reasoned action, theory of planned behavior, stimulus organization and response model, technology acceptance model (TAM) have been examined (Muthitcharoen et al., 2011).

The combination of themes involving online purchase intention and brand personality was the subject of study by researchers in recent years. The diagram below which is extracted from Thomson Reuters, displays the trend of publications for the above terms:

\section{Web of Science ${ }^{\circledR}$}

\section{«Back to previous page \\ Citation Report Topic=(brand personality) AND Topic=(purchase intention) Timespan $=$ All years. Databases $=$ SCI-EXPANDED, SSCI, A\&HCl, CPCI-S, CPCI-SSH}

This report reflects cittations to source items indexed within Web of Science. Perform a Cited Reference Search to include citations to iterns not indexed within Web of Science.
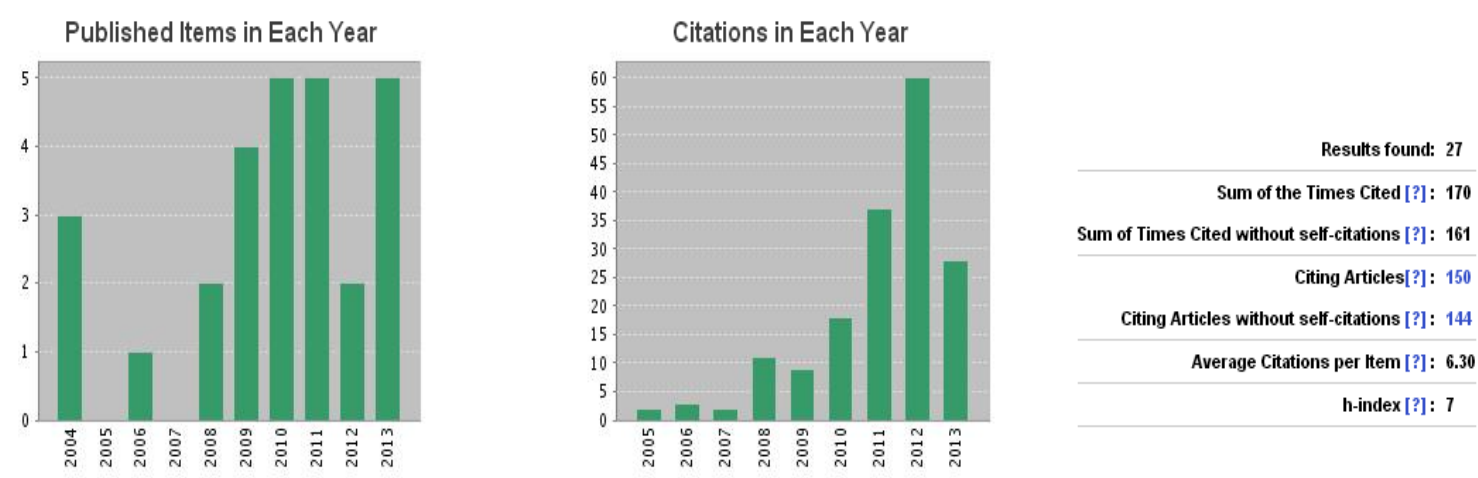

Figure 1. Trends of brand personality and purchase intention in web of science

The diagram below presents the share of the above two terms on the basis of common keyword plus, used by researchers in online environment and is extracted from web of science. 


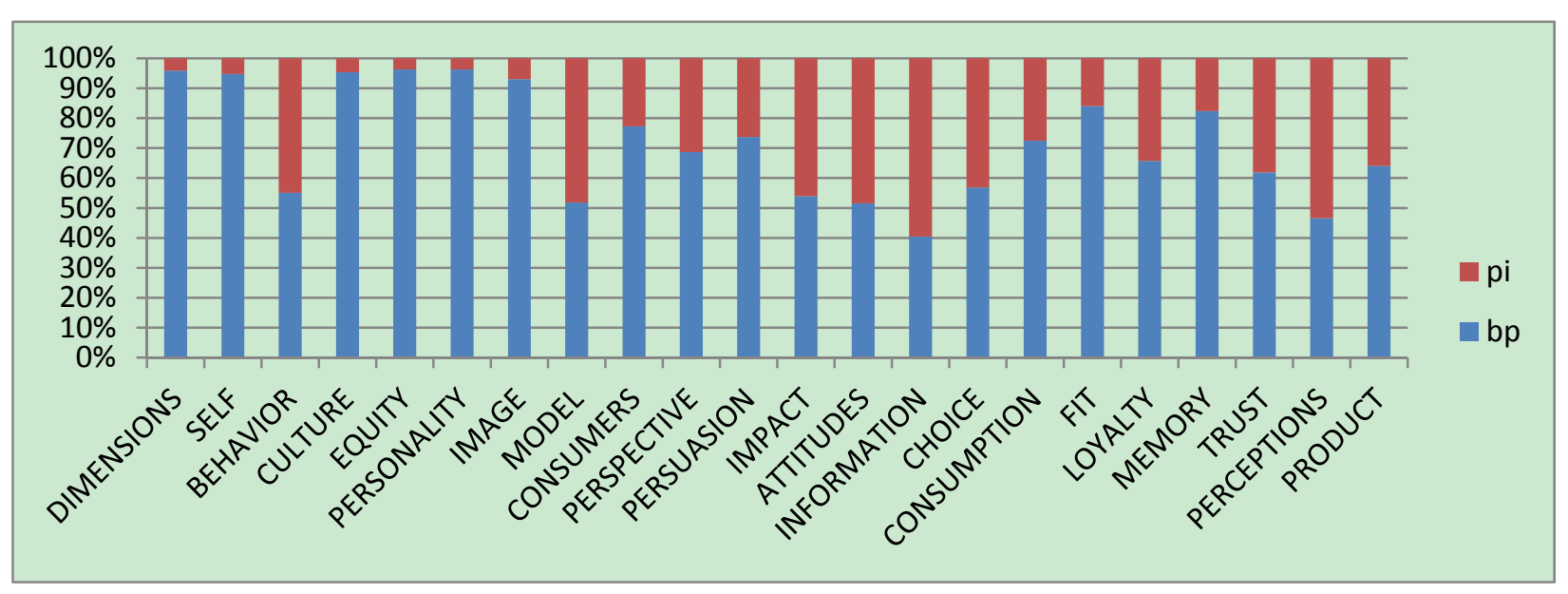

Figure 2. Percentile common keyword plus between brand personality and purchase intention

Taking into account the above facts and to address the gaps in research, this study focused on the following:

- To clarify whether brand personality moderates the relationship between website quality and online trust in affecting consumers' purchase intentions in an online environment.

- To examine the extent of influence of website quality on online trust in the context of Malaysian online environment.

- To examine the degree of influence of online trust on consumers' intention to purchase in the context of Malaysian online environment.

\section{Conceptual Framework and Literature Review}

\subsection{Conceptual Framework}

Figure 3 highlights the research framework derived from the stimulus-organism-response (S-O-R) paradigm (Mehrabian \& Russell, 1974). This model is often applied to examine the cause and effect of the perceived online store characteristics on consumer behavior (Jeong et al., 2009). In an online shopping environment, the stimulus is the website atmosphere as it could have a persuasive effect on the state of mind of the customer. The consumers' state of mind is an important determinant that could influence their reactions and decisions. Based on prior research, this study defines the stimulus as the tangible cues eg., website technical adequacy, content quality, specific content and appearance.

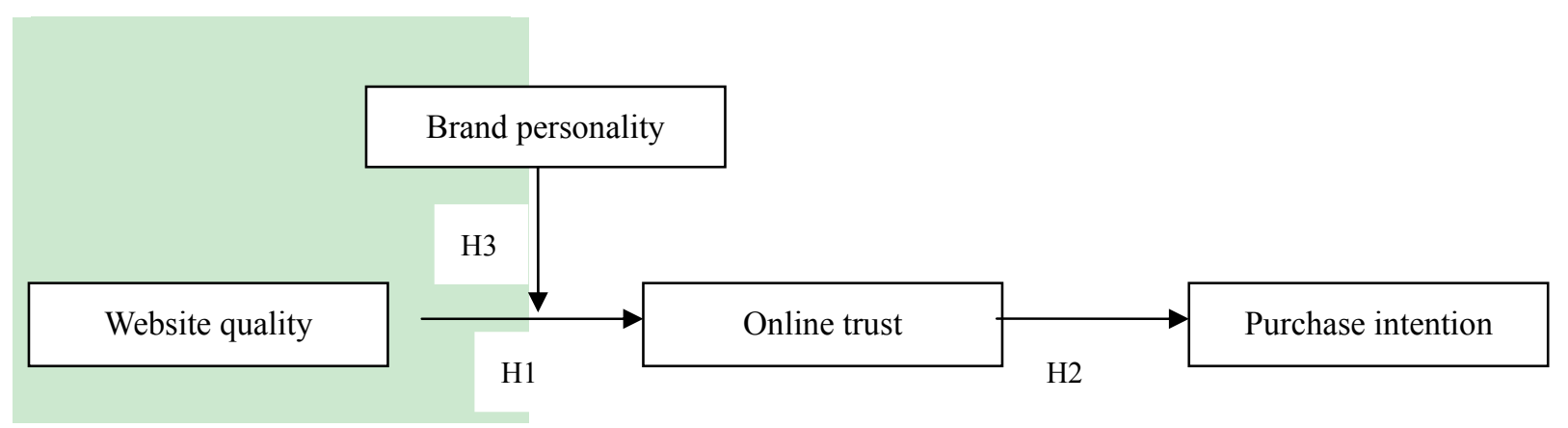

Figure 3. Research model

The final outcomes in the S-O-R paradigm, namely response, the heading off or approach behavior of the consumer (Donovan \& Rossiter, 1982; Sherman et al., 1997) and purchase intention are the preferred construct to examine the response to exposure to online stimuli (Kawaf \& Tagg, 2012).

The study by (Müller \& Chandon, 2003) provides an insight into brand personality applications in an online environment in France. Their study explored the effects of a website on brand personality. On the other hand, 
(Poddar et al., 2009) also conceptualized and measured brand personality in an online environment. This study would outline the moderating effects of brand personality on online retailing in the Malaysian context.

\subsection{Website Quality}

Website quality refers to a measure of excellence of the website, based on users' evaluations on the features in satisfying their requirements (Aladwani \& Palvia, 2002). Several dimensions of website quality have been ascertained and enumerated in various studies. However, these studies on website quality were more concerned about issues relating to the salient design features or usability attributes of websites.

(Liu \& Arnett, 2000) highlighted information and service quality, system use, playfulness and system design quality as key dimensions of website quality. (Huizingh, 2000) argued that there are only two types of web quality: content and design. However, (Wan,2000) identified four attributes of website quality: information, friendliness, responsiveness and reliability. (Rose et al. (1999) recognized the importance of features such as download speed, web interface, search functionality, measurement of web success, security and internet standards as indicative of website quality. (Aladwani \& Palvia, 2002) in an effort to develop a reliable instrument to measure website quality from the user's perspective, established four underlying dimensions, namely, technical adequacy, content quality, specific content and appearance. This paper would highlight the development of an instrument that is able to incorporate key characteristics of website quality from the user's perspective.

The technical adequacy indicates that appropriate technologies have been adopted by the web retailer, such as ease of navigation, speed of page loading and valid links. Content validity deals with attributes such as information usefulness, completeness and accuracy. Specific content provides detailson product/ services, customer support, privacy policies and other important information. Appearance refers to the visual attractiveness of web site, such as colors, fonts and multimedia features (Aladwani \& Palvia, 2002; Chang \& Wang, 2008; Ranganathan \& Ganapathy, 2002).

\subsection{Online Trust}

Online trust is also an important factor that is essential for both business to business and business to consumers transactions (Alam \& Yasin, 2010). Gefen (2000) explored the role of trust in the context of online bookstores and discovered that trust is a major factor influencing customers' intention to purchase from online bookstores. Other studies have also drawn similar conclusions, implying that online trust is crucial in determining customers' purchase decisions (Kim \& Lennon, 2008).

Thus, it could be concluded that online trust is one of the key challenges that vendors face in their pursuit to succeed on the internet medium. A lack of trust would discourage and dissuade online consumers from doing transactions through websites (Chen \& Barnes, 2007). Thus, it is imperative to enhance and nurture online trust as it lends credibility to online transactions and could be instrumental to the success or failure of online retailers and vendors (Karimov et al., 2011)

In summary, it could be said that the growth of internet has generated an increasing interest in exploring the concept of trust (Sillence et al., 2006). Corritore et al. (2003) defined online trust as a relationship or bond that exists between an individual and his interactions with the internet. They had further examined other fundamental characteristics of trust and perceived credibility.

\subsection{Brand Personality}

Brand personality relates to an identification of a product or service which has the potential to significantly influence consumer behavior (Louis \& Lombart, 2010). Research on brand personality is usually conducted in an offline environment, but (Müller \& Chandon, 2003) conducted an experiential study in an online context and discovered two of the brand personality dimensions, youthfulness/modernity and sincerity/trustworthiness appealed more to the study group, thus increasing the access to their websites. The study also indicated that this effect strengthened as visitors to the brand website exhibited a more positive attitude towards the site. Much of earlier research focused primarily on the dimensions of brand personalities of consumer goods and services, but the study by (Poddar et al., 2009) extended the conceptualization and measurement of brand personality to an online context.

Brand personality could be viewed as a set of human characteristics associated with a brand (Aaker, 1997). Aakerhas classified these humanlike characteristics into five distinct dimensions, namely sincerity, excitement, competence, sophistication and ruggedness and a total of 42 personality traits were identified to underlie these five categories. 
It has been found that websites also could evolve and mold brand personalities (Chen \& Rodgers, 2006) and as such, they are likely to reflect human personality characteristics as well. The website personality could be defined as a set of traits encompassing human characteristics and information technology features of a website (Chen \& Rodgers, 2006: 49-50). Thus, it is imperative to recognize that design has an integral role in shaping website personality. They advanced the notion that in essence website brand personality influences the relationship between consumers and brands, as well as improves the effectiveness of online transactions.

\subsection{Purchase Intention}

Purchase intention relates to a state of mind of the consumer which indicates an inclination or probability that he would purchase the product. The stimulus- organism- response (S-O-R) paradigm as a theoretical framework, could be applied to assess the effect of website features on web consumers and their behavior (Eroglu et al., 2001; Wells et al., 2011). This model examines therole of cognitive and affective reactions to website interactivity in influencing users' purchase intentions. The S-O-R model posits that environmental cues act as stimuli that affect an individual's cognitive and affective reactions, which in turn affects behavior (Mehrabian \& Russell, 1974). Stimuli could manifest in different formats such as website quality (Jacoby, 2002)

\subsection{Hypotheses Development}

McKnight et al. (2004) indicated that perceived website quality relates positively to both trusting belief and intentions as the website provides the initial indication of the vendor's presence, thus giving rise to preliminary impressions. Therefore, if a consumer regards the website is of high quality, then it is possible that there would be higher level of trusting belief on the online retailer's competence, integrity and benevolence which could foster a willingness to purchase (Harrison McKnight et al., 2002).

In addition, (Lowry et al., 2008) posited that website quality in unison with branding could elevate consumer trust of e-commerce websites. If buyers develop a trust as a result of dealing with the vendor, it could contribute to a higher level of purchase intentions(Hsu et al., 2012). Thus, basis of trust should be nurtured with consumers as it is precursor to consumer purchase intentions (Van der Heijden et al., 2003). As indicated in previous research, customer trust is essential to positively induce customer purchase intentions (Schlosser et al., 2006; Chen \& Barnes, 2007). Hence, this study has developed the following hypotheses:

H1: Perceptions of consumers on website quality influence their trust towards online purchase intentions.

H2: Consumers' trust positively affects online purchase intentions.

Website brand personality refers to the mental representation of a website store that include dimensions that are similar and reflect the characteristics of human personality (Poddar et al., 2009).In other words, it is "set of human characteristics associated with brand" (Aaker, 1997). For example, if consumers associate a particular product with sophisticated looking purchasers, then the product could evolve a sophisticated brand personality. If the website contains exciting features that delight the users, then that website personality could increase the level of trust through building strong relationships between the qualities of that website. An example of an exciting feature in a website is social feedback, such as transactions on ebay.com that tracks sales and requests, enabling a compilation on customer purchasing habits which could be leveraged upon to gauge the customer's reputation (Zhang \& von Dran, 2002). Kim and Lehto (2013) who examined the official Korean tourism website to assess the destination personality found that excitement personality dimension and sincerity of website are dominant features that appealed to its users.

H3: brand personality moderates the relationship between the website quality and online trust.

\section{Method}

\subsection{Questionnaire Development}

A survey was undertaken by administering questionnaires to the respondents comprising 229 college students in Malaysia. The questionnaire was designed to contain three parts. In part one, respondents were required to identify an online retailer website that they frequently browsed. In addition, the questionnaire also assessed the experience and knowledge of the respondents with regards to website quality. In part two, the questionnaire included various measures to evaluate the feelings of the respondents towards a specific website. The questionnaire used seven-point likert type items on a scale of $1=$ strongly disagree to $7=$ strongly agree, to indicate the feelings. Perceived website quality was measured by 25 items as proposed by (Aladwani and Palvia, 2002) and the scale was further examined to determine its reliability (Liao et al., 2006). Online trust was assessed by nine measures modified from (Gefen \& Straub, 2004). The scale was further examined by (Hwang \& Kim, 2007) who found them to have high reliability. Online purchase intention was assessed by three measures 
modified from (Pavlou, 2003) whereas website brand personality was assessed by (Müller \& Chandon, 2003). Part three contained some general questions on the profile of respondents such as ethnicity, education and age.

\subsection{Pilot Test}

A preliminary survey instrument was tested in a pilot study with a small sample among Malaysians comprising different ethnicities such as Malays, Indians and Chinese. There were a total of 35 responses, resulting in a response rate of 100 percent. The results of the pilot study were evaluated using Cronbach's reliability and factor analysis. Cronbach's alpha indicator was used to assess the initial reliability of the scales. The threshold of acceptability for Cronbach's alpha is 0.7 (Hair et al., 1998). The results of Cronbach's alpha are enumerated below:

\subsection{Sampling Plan and Data Collection}

Data collection was carried out through questionnaires using the direct contact approach, The respondents for the survey were college and university students in , Malaysia, having varying educational levels These students were selected for the study as they were most active and frequent users of internet and access different websites, compared to the other population segments (Kim \& LaRose, 2004). There were 229 respondents to the survey. Males comprised 48 percent of the respondents, As for the academic qualifications of the respondents, 21 per cent had diplomas, 49 per cent had bachelor's degree, 25 per cent were with master's degree and 5 per cent had doctorates.

Table 1. Age frequency of respondents

\begin{tabular}{ll}
\hline Age & Frequency(percent) \\
\hline 18 to 20 & 4.4 \\
20 to 25 & 55.5 \\
26 to 30 & 17 \\
31 to 35 & 10.9 \\
36 to 40 & 7.9 \\
41 to 45 & 3.1 \\
45 and above & 1.3 \\
\hline
\end{tabular}

The composition of the sample population was 53.7 per cent Malays, 34.5 per cent Chinese and 11.8 per cent Indians.

All the respondents $(100 \%)$ had been using internet for more than a year. Of this, 72.5 per cent had online shopping experience while 27.5 per cent had no experience of online shopping.

\section{Data Analysis and Computing}

\subsection{Normality Test}

The data were checked for possible violations of the assumptions of multiple regression analysis, prior to conducting the analysis. To check for normality of data, skewness and kurtosis were measured, which were acceptable at a near value of \pm 1 and \pm 4 , respectively. (Field, 2009)

Table 2. Website quality dimensions

\begin{tabular}{|c|c|c|c|c|c|c|}
\hline VARIABLES & MEAN & 5\% TRIMMED MEAN & \multicolumn{2}{|c|}{ SKEWNESS } & \multicolumn{2}{|c|}{ KURTOSIS } \\
\hline TECHNICAL ADEQUACY* & 5.47 & 5.51 & -.770 & .161 & .984 & .32 \\
\hline CONTENT QUALITY* & 5.33 & 5.34 & -.195 & .161 & -.364 & .32 \\
\hline SPECIAL CONTENT* & 5.11 & 5.13 & -.243 & .161 & -.395 & .32 \\
\hline APPEARANCE* & 5.48 & 5.51 & -.414 & .161 & -.139 & .32 \\
\hline ONLINE TRUST & 5.27 & 5.29 & -.454 & .161 & -.71 & .32 \\
\hline PURCHASE INTENTION & 4.99 & 5.03 & -.638 & .161 & .737 & .32 \\
\hline BRAND PERSONALITY & 5.12 & 5.14 & -.332 & .161 & -.63 & .32 \\
\hline
\end{tabular}




\subsubsection{Correlation among Research Variables}

To study the correlation among the constructs of the research model, Pearson correlations were applied. The correlation coefficient between two constructs, ranged from 0.305 to 0.722 , as shown in the table below and they all were found to be significant in this study. All the constructs, namely the dependent variable, independent variable, moderator and mediator variables were observed to have significant correlation.

Table 3. Correlations among variables

\begin{tabular}{lllllll}
\hline & $\begin{array}{l}\text { Technical } \\
\text { adequacy }\end{array}$ & $\begin{array}{l}\text { Content } \\
\text { quality }\end{array}$ & $\begin{array}{l}\text { Special } \\
\text { content }\end{array}$ & $\begin{array}{l}\text { Appeara } \\
\text { nce }\end{array}$ & $\begin{array}{l}\text { Online } \\
\text { trust }\end{array}$ & $\begin{array}{l}\text { Purchase } \\
\text { intention }\end{array}$ \\
\hline $\begin{array}{l}\text { Content } \\
\text { quality }\end{array}$ & $.718^{* *}$ & & & & & \\
Special & $.609^{* *}$ & $.611^{* *}$ & & & & \\
content & & & & & & \\
appearance & $.683^{* *}$ & $.722^{* *}$ & $.564^{* *}$ & & & \\
$\begin{array}{l}\text { Online trust } \\
\text { Purchase }\end{array}$ & $.623^{* *}$ & $.681^{* *}$ & $.606^{* *}$ & $.671^{* *}$ & & \\
intention & $.305^{* *}$ & $.434^{* *}$ & $.360^{* *}$ & $.422^{* *}$ & $.499^{* *}$ & \\
$\begin{array}{l}\text { Brand } \\
\text { personality }\end{array}$ & $.606^{* *}$ & $.669^{* *}$ & $.567^{* *}$ & $.661^{* *}$ & $.717^{* *}$ & $.452^{* *}$ \\
\hline
\end{tabular}

Note. ${ }^{* *}$ Correlation is significant at the 0.01 level (2-tailed).

\subsection{Factor Analysis}

Factor analysis is a technique that allows for reduction of data set with a large number of variables to one with a smaller number of factors. In this study, Confirmatory factor analysis was used to verify the two brand personality dimensions, as suggested by (Müller \& Chandon, 2003)

Table 4. Extraction method: principal component analysis (rotation method: Varimax with Kaiser normalization)

\begin{tabular}{lll}
\hline & Component & 2 \\
\hline innovative & 1 & \\
modern & 0.806 & \\
imaginative & 0.8 & \\
trendy & 0.781 & \\
bold & 0.765 & \\
likeable & 0.749 & \\
dynamic & 0.634 & \\
cheerful & 0.607 & \\
unique & 0.605 & 0.864 \\
lookreliable & 0.52 & 0.864 \\
safe & & 0.855 \\
trustworthy & & 0.634 \\
sincere & & 0.624 \\
authentic & & 0.533 \\
elegant & & \\
\hline
\end{tabular}


The Kaiser - Meyer -Oklin (KMO), a sampling adequacy test for verifying partial correlation among variables, showed a score of 0.925 , which was well above the recommended 0.5 level (Malhotra, 2008). Further the Bartlett's test of sphericity indicated that there was adequate correlation among the chosen variables $\left(x^{2}(229)\right.$ $=2179, \mathrm{p}<.000$ ). In this survey, the items with factor loading above 0.5 , namely innovative, modern, imaginative, trendy, bold, likeable, dynamic, cheerful and unique are classified under the group "youthfulness/modernity". Other items such as looks reliable, safe, trustworthy, sincere, authentic and elegant are categorized under "sincerity/trustworthiness". This is in line with the experiential study conducted by (Müller and Chandon, 2003).The first group is called brand 1, that is "youthfulness/modernity", while the second group is brand 2, that is "sincerity/trustworthiness".

\subsection{Testing Moderating Effects Using Multiple Regression}

\subsubsection{Brand Personality Moderate Technical Adequacy and Online Trust Relationship}

The independent variable dimensions, namely technical adequacy (TA), content quality (CQ), special content (SC) and appearance (APP) were standardized as well as the moderator variable which is brand personality. The effects of demographic variables on online trust were excluded from the analysis. Figures 4, 5, 6 and 7 graphically represent the linear relationship between the four dimensions of website quality (TA, CQ, SP, APP) and online trust relationship, with respect to three categorized values of youthfulness/modernity and sincerity/trustworthiness. The first and second dimensions of brand personality are categorized as mean (mean youthfulness/modernity), mean - standard deviation (low youthfulness/modernity) and mean+ standard deviation (high youthfulness/modernity) and mean(mean sincerity/trustworthiness ), mean- standard deviation(low sincerity/trustworthiness) and mean +standard deviation (high sincerity/trustworthiness ).

The results as in Table 5 reveal that both dimensions of brand personality significantly moderate the effect of TA on online trust. The R squares of both models were $48.8 \%$ and $68.7 \%$, respectively.

Table 5. Summary of multiple regression analyses for moderating effect of brand 1 and brand 2 on the relation between TA website quality and online trust

\begin{tabular}{lcccccc}
\hline \multirow{2}{*}{ Predictor variables } & \multicolumn{3}{c}{ Brand 1 } & \multicolumn{3}{c}{ Brand 2 } \\
\cline { 2 - 7 } $\mathrm{TA}$ & $\mathrm{B}$ & $\mathrm{t}$ & $\mathrm{p}$ value & $\mathrm{B}$ & $\mathrm{t}$ & $\mathrm{p}$ value \\
\cline { 2 - 7 } $\mathrm{TA}$ *Brand & 0.866 & 4.336 & 0.000 & 0.630 & 4.070 & 0.000 \\
\hline $\mathrm{R}^{2}$ & -0.107 & -2.534 & 0.012 & -0.080 & -2.554 & 0.011 \\
$\mathrm{~F}$ & & 0.4885 & & & 0.687 \\
$\mathrm{p}$ value & & 29.06 & & & 66.647 \\
\hline
\end{tabular}

Dependent Variable: ONLINETRUST

The results in figure 4 reflect a positive influence of technical adequacy on online trust. However the effect of web site technical adequacy on online trust appears to be more of a moderating nature of modernity/youthfulness dimension of brand personality compared to the moderating effect of sincerity/trustworthiness in the above relationship. Online trust is more influenced by technical issues such as ease of navigation or speed of page loading, while brand personality of web site is categorized as low modern/youthfulness compared to mean category or highly youthful/modern. The earlier term used for youthfulness was "excitement", as proposed by Ferrandi et al (1999). Therefore we could conclude that if the web site is less imaginative or exciting, the influence of technical adequacy on the online trust would be greater. The outcome would be similar for content quality, special content and appearance as shown in Figure 4 below. 

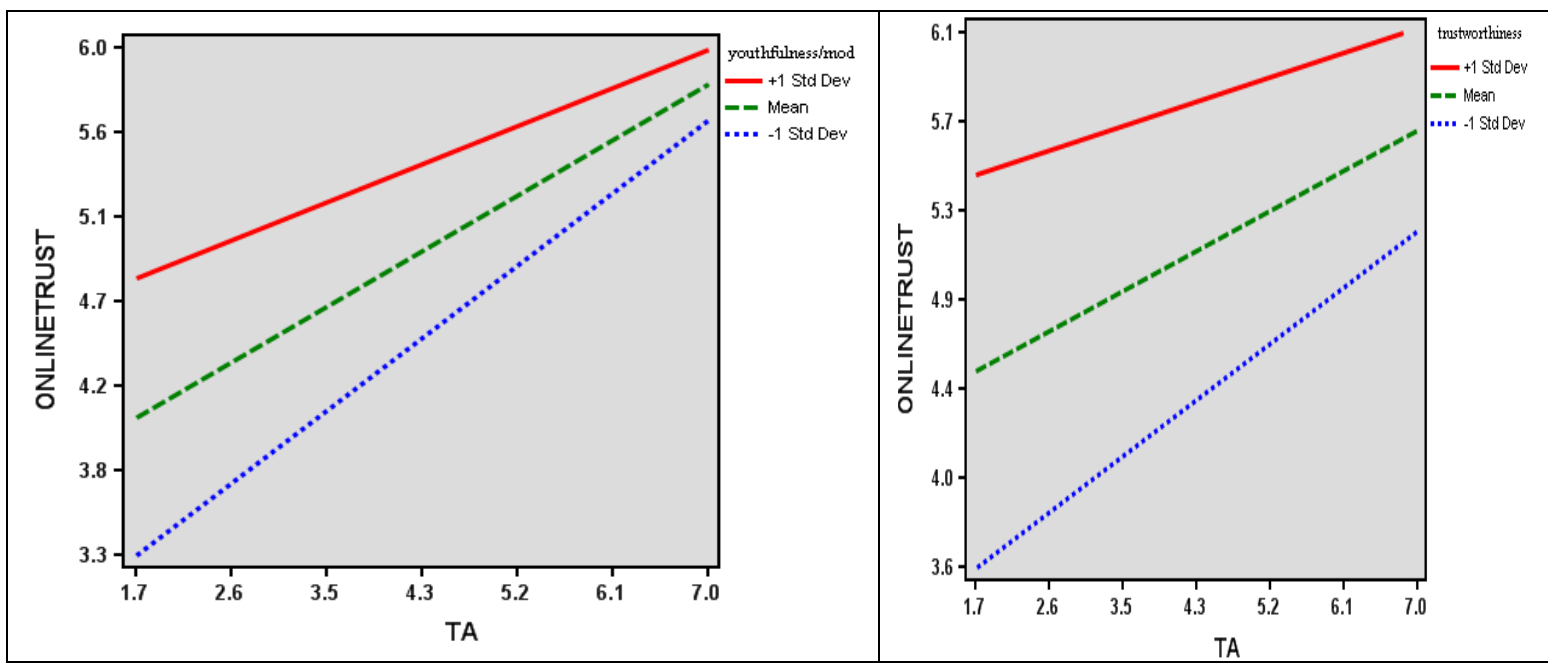

Figure 4. Interaction between technical adequacy and brand personality on relationship with online trust

The moderator role of youthfulness/modernity (brand1) and sincerity/trustworthiness (brand2) in the relationship between technical adequacy and online trust could be considered as quazi moderating.

\subsubsection{Brand Personality Moderate Content Quality and Online Trust Relationship}

The results in Table 6 depict the positive effect of content quality on online trust. The R squares of both models were $55.5 \%$ and $67.8 \%$, respectively.

Table 6. Summary of multiple regression analyses for moderating effect of brand 1 and brand 2 on the relation between CQ website quality and online trust

\begin{tabular}{lcccccc}
\hline \multirow{2}{*}{ Predictor variables } & \multicolumn{3}{c}{ Brand 1 } & \multicolumn{3}{c}{ Brand 2 } \\
\cline { 2 - 7 } $\mathrm{CQ}$ & $\mathrm{B}$ & $\mathrm{t}$ & $\mathrm{p}$ value & $\mathrm{B}$ & $\mathrm{t}$ & $\mathrm{p}$ value \\
\cline { 2 - 7 } $\mathrm{CQ}$ Brand & 0.809 & 3.602 & 0.000 & 0.683 & 0.185 & 0.000 \\
\hline $\mathrm{R}^{2}$ & -0.052 & -1.151 & 0.251 & -0.077 & 0.036 & 0.034 \\
$\mathrm{~F}$ & & 0.555 & & & 0.678 \\
$\mathrm{p}$ value & & 37.951 & & & 63.991 \\
\hline
\end{tabular}

Dependent Variable: ONLINETRUST
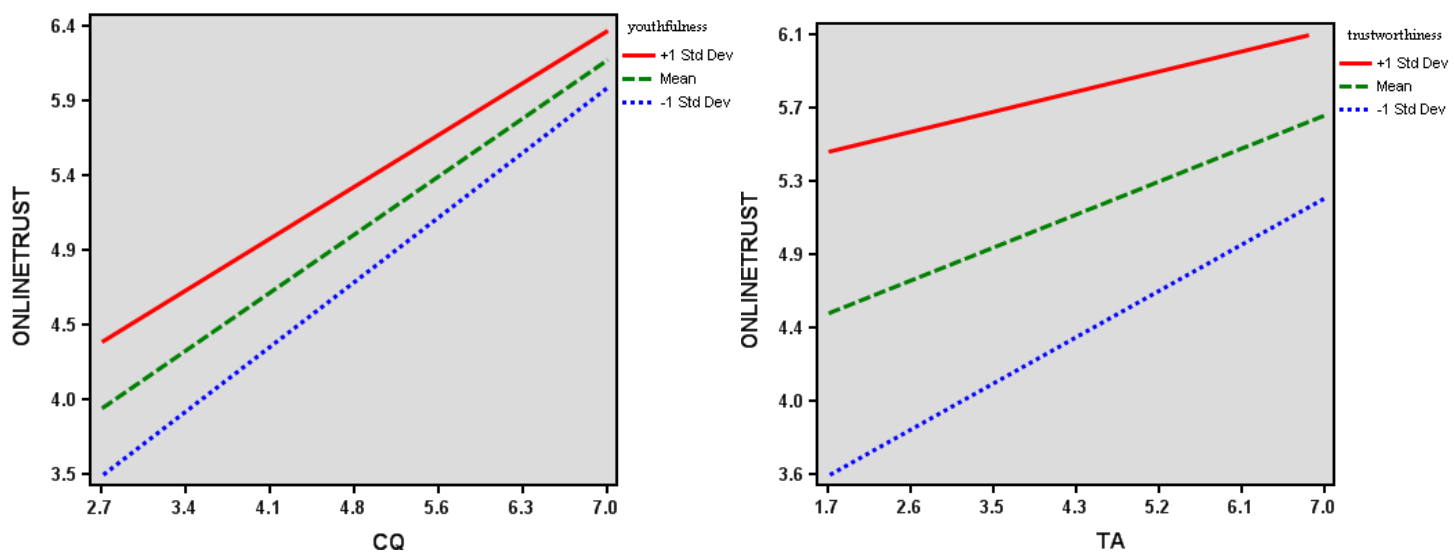

Figure 5. Interaction between CQ and brand personality on relationship with online trust 
The moderating role of youthfulness/modernity (brand1) with respect to the relationship between content quality and online trust is homologizer, while the moderating role of sincerity/trustworthiness (brand2) in the relationship between content quality and online trust is quazi moderating.

\subsubsection{Brand Personality Moderate Specific Content and Online Trust Relationship}

The results in Table 7 reflect a positive influence of specific content on online trust. It revealed that both dimensions of brand personality significantly moderate the effect of content quality on online trust. The $\mathrm{R}$ squares of both models were $50.3 \%$ and $68.4 \%$, respectively.

The results in Table 7show the positive effect of special content on online trust. The R squares of both models were $50.3 \%$ and $68.4 \%$, respectively.

Table 7. Summary of multiple regression analyses for moderating effect of brand 1 and brand 2 on the relation between SC website quality and online trust

\begin{tabular}{lcccccc}
\hline Predictor variables & \multicolumn{3}{c}{ Brand 1 } & \multicolumn{3}{c}{ Brand 2 } \\
\cline { 2 - 7 } & $\mathrm{B}$ & $\mathrm{t}$ & $\mathrm{p}$ value & $\mathrm{B}$ & $\mathrm{t}$ & $\mathrm{p}$ value \\
\cline { 2 - 7 } $\mathrm{SC}$ & 1.041 & 4.999 & 0.000 & 0.606 & 3.818 & 0.000 \\
$\mathrm{SC} \mathrm{F}^{*}$ Brand & -0.136 & -3.276 & 0.001 & -0.072 & -2.348 & 0.020 \\
$\mathrm{R}^{2}$ & & 0.503 & & & 0.684 & \\
$\mathrm{~F}$ & & 30.785 & & & 65.891 \\
$\mathrm{p}$ value & & 0.000 & & & 0.000 & \\
\hline
\end{tabular}

Dependent Variable: Online trust.
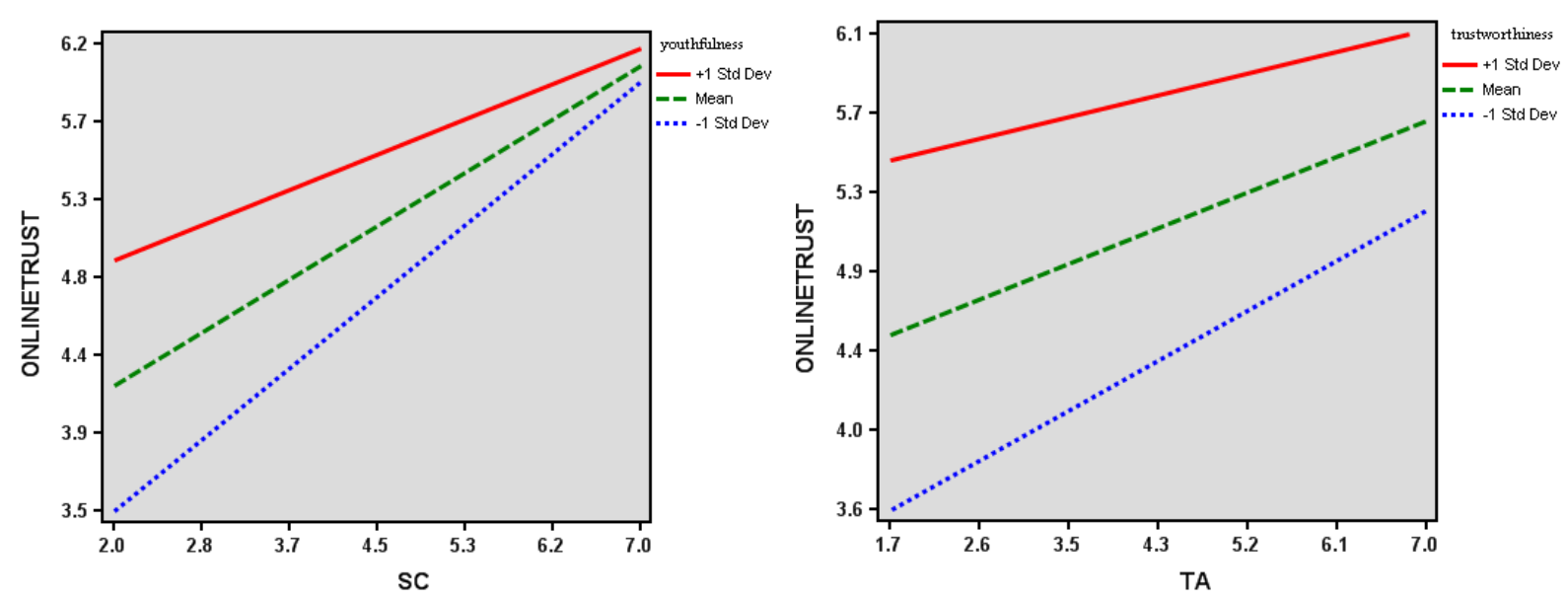

Figure 6. Interaction between sc and brand personality on relationship with online trust

The role of youthfulness/modernity (brand1) and sincerity/trustworthiness (brand2)as moderators in the relationship between special content and online trust could be categorized as quazi moderating.

\subsubsection{Brand Moderating of APP and Online Trust Relationship}

Table 8 displays a positive influence of appearance on online trust. The R squares of both models were $51.4 \%$ and $68 \%$, respectively. 
Table 8. Summary of multiple regression analyses for moderating effect of brand 1 and brand 2 on the relation between APP website quality and online trust

\begin{tabular}{lcccccc}
\hline Predictor variables & \multicolumn{3}{c}{ Brand 1 } & \multicolumn{3}{c}{ Brand 2 } \\
\cline { 2 - 7 } & $\mathrm{B}$ & $\mathrm{t}$ & $\mathrm{p}$ value & $\mathrm{B}$ & $\mathrm{t}$ & $\mathrm{p}$ value \\
\cline { 2 - 7 } APP & 0.998 & 4.764 & 0.000 & 0.670 & 3.819 & 0.000 \\
APP*Brand & -0.118 & -2.675 & 0.008 & -0.084 & -2.367 & 0.018 \\
$\mathrm{R}^{2}$ & \multicolumn{3}{c}{0.514} & & & 0.680 \\
$\mathrm{~F}$ & & 32.146 & & & 64.627 \\
$\mathrm{p}$ value & & 0.000 & & & 0.000 \\
\hline
\end{tabular}

Dependent Variable: Online Trust.

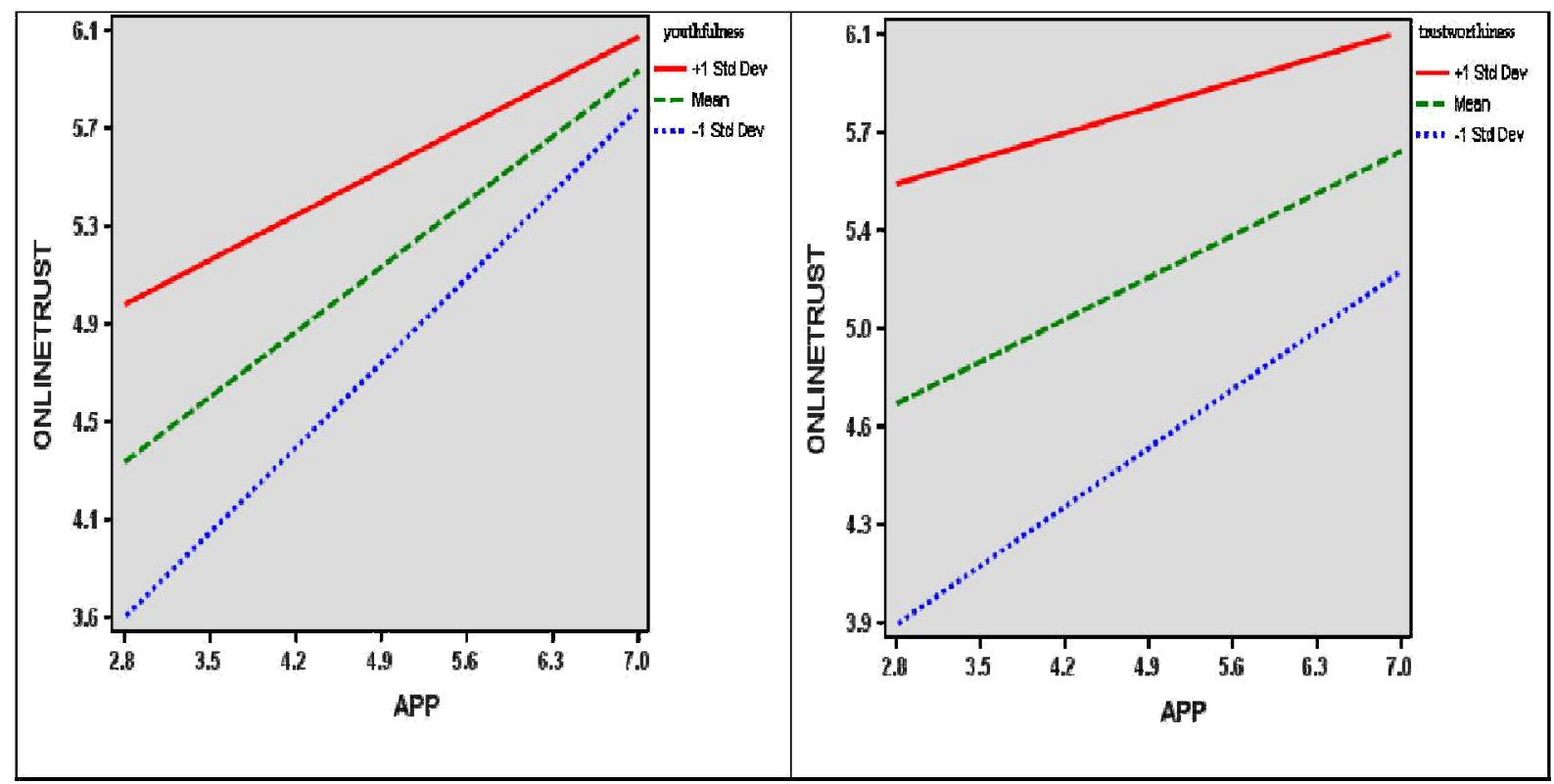

Figure 7. Interaction between appearance and brand personality on relationship with online trust

The moderating role of youthfulness/modernity (brand 1) and sincerity/trustworthiness (brand 2) in the relationship between appearance and online trust could be viewed as quazi moderating.

\subsection{Testing the Relationship of Online Trust and Purchase Intention}

The linear regression analysis was carried out to analyze the impact of online trust on purchase intention. The results are shown in Table 8. It displays the regression analysis with online trust as an independent variable and purchase intention as a dependent variable. The linear regression was used to examine to what extent the proposed linear regression is supported by the research data. The regression examined how well the purchase intention could be predicted by online trust. The general equation of the relation is as below:

$$
\mathrm{Y}=1.751+.615 \mathrm{X}_{1}+\varepsilon
$$

$\mathrm{b}_{0}=$ constant (intercept)

$\mathrm{b}_{1}=$ slope (estimates of coefficients)

$\mathrm{Y}_{1}=$ purchase intention

$\mathrm{X}_{1}=$ online trust 
The results in Table 9 shows that online trust has a significant effect on purchase intentions and the hypotheses 2 are therefore accepted.

Table 9. Summary of linear regression analyses for the relationship between online trust and purchase intention

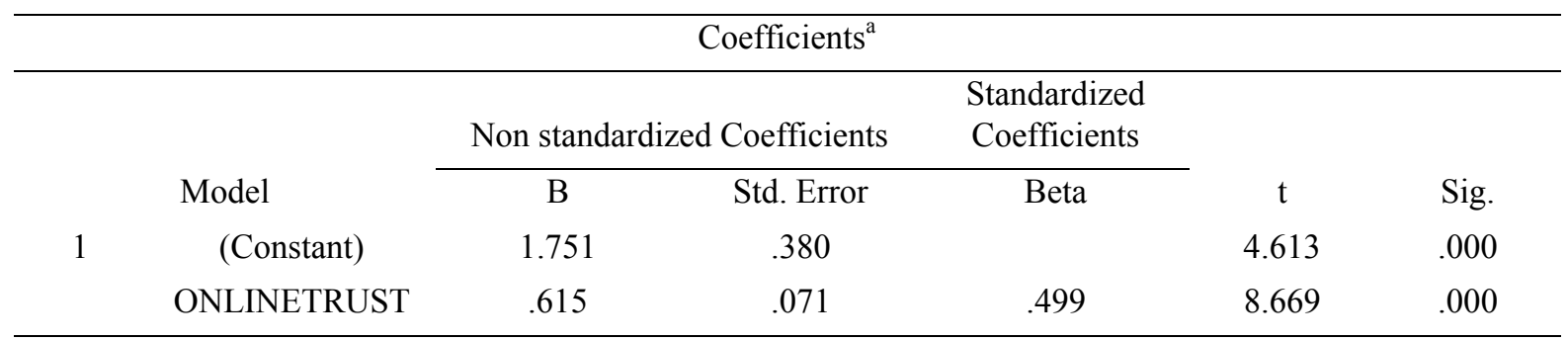

\section{Conclusion and Implications}

The findings of this study have raised some important issues concerning online environment cues and customers' purchase decisions that have not been addressed in previous studies, particularly in the Malaysian context. This study reveals that brand personality moderates the relationship between website quality and online trust. The modernity/youthfulness dimension of brand personality has a more significant moderating effect rather than the sincerity/trustworthiness dimension of brand personality. Moreover the results indicate that imaginative websites could be more influential. Thus this study suggests that online retailers should consider focusing their marketing strategies more on establishing a modern and exciting website compared to placing emphasis on the trustworthiness aspect, especially for the Malaysian market. This would enhance the relationship between customers and websites and subsequently increase the volume of online transactions.

The finding shows that there is a significant relationship between website quality and online trust and the result leads to acceptance of hypothesis one. Appearance, content quality, technical adequacy as well as special content have significant influence on online trust in the Malaysian context.

Furthermore hypothesis two and three are also accepted, as there is a significant relationship between online trust and purchase intention, and brand personality does play a moderating role as well.

\section{Limitation and Future Research}

This study focused on user's perceptions of websites based on their browsing experience. As the browsing took place prior to data collection, the effect of timing on the changes in their perception of the importance of various web quality factors was not captured. In addition, various factors such as internet experience, the type of web site (e.g music CDs, books, travels, computers, apparel and cosmetics) and incentive programs might also influence the users' perceptions of website quality, awareness, image, trust and risks. However these factors were not incorporated into the scope of this study. Further studies are therefore necessary to explore their impact on consumers' online purchase intentions. As the respondents of this study are students, future studies could cover a wider section of the population.

\section{References}

Aaker, J. L. (1997). Dimensions of brand personality. Journal of Marketing Research, $347-356$. http://dx.doi.org/10.2307/3151897

Aladwani, A. M., \& Palvia, P. C. (2002). Developing and validating an instrument for measuring user-perceived web quality. Information \& Management, 39, 467-476. http://dx.doi.org/10.1016/S0378-7206(01)00113-6

Alam, S. S., \& Yasin, N. M. (2010). The antecedents of online brand trust: Malaysian evidence. Journal of Business Economics and Management, 210-226. http://dx.doi.org/10.3846/jbem.2010.10

Chang, H. H., \& Wang, I. C. (2008). An investigation of user communication behavior in computer mediated environments. Computers in Human Behavior, 24, 2336-2356. http://dx.doi.org/10.1016/j.chb.2008.01.001

Chen, Q., \& Rodgers, S. (2006). Development of an instrument to measure web site personality. Journal of Interactive Advertising, 7. http://dx.doi.org/10.1080/15252019.2006.10722124

Chen, S. C., \& Dhillon, G. S. (2003). Interpreting dimensions of consumer trust in e-commerce. Information Technology and Management, 4, 303-318. http://dx.doi.org/10.1023/A:1022962631249 
Chen, Y. H., \& Barnes, S. (2007). Initial trust and online buyer behaviour. Industrial Management \& Data Systems, 107, 21-36. http://dx.doi.org/10.1108/02635570710719034

Corritore, C. L., Kracher, B., \& Wiedenbeck, S. (2003). On-line trust: concepts, evolving themes, a model. International Journal of Human-Computer Studies, 58, 737-758. http://dx.doi.org/10.1016/S10715819(03)00041-7

Cyr, D., Head, M., \& Larios, H. (2010). Colour appeal in website design within and across cultures: A multimethod evaluation. International Journal of Human-Computer Studies, 68, 1-21. http://dx.doi.org/10.1016/j.ijhcs.2009.08.005

Donovan, R. J., \& Rossiter, J. R. (1982). Store atmosphere: an environmental psychology approach. Journal of retailing, 58, 34-57.

Eroglu, S. A., Machleit, K. A. \& Davis, L. M. (2001). Atmospheric qualities of online retailing: a conceptual model and implications. Journal of Business research, 54, 177-184. http://dx.doi.org/10.1016/S01482963(99)00087-9

Éthier, J., Hadaya, P., Talbot, J. \& Cadieux, J. (2006). B2C web site quality and emotions during online shopping episodes: An empirical study. Information \& Management, 43, 627-639. http://dx.doi.org/10.1016/j.im.2006.03.004

Field, A. (2009). Discovering statistics using SPSS, Sage publications.

Fournier, S. (1998). Consumers and their brands: developing relationship theory in consumer research. Journal of consumer research, 24, 343-353. http://dx.doi.org/10.1086/209515

Gefen, D. (2000). E-commerce: the role of familiarity and trust. Omega, 28, 725-737. http://dx.doi.org/10.1016/S0305-0483(00)00021-9

Gefen, D. \& Straub, D. W. (2004). Consumer trust in B2C e-commerce and the importance of social presence: $\begin{array}{lllll}\text { experiments in e-products and } & \text { e-services. }\end{array}$ http://dx.doi.org/10.1016/j.omega.2004.01.006

Hair, J. F., Anderson, R. E., Tatham, R. L., \& Black, W. C. (1998). Multivariate analysis. Englewood: Prentice Hall International.

Harris, L. C., \& Goode, M. M. (2010). Online servicescapes, trust, and purchase intentions. Journal of Services Marketing, 24, 230-243. http://dx.doi.org/10.1108/08876041011040631

Harrison Mcknight, D., Choudhury, V., \& Kacmar, C. (2002). The impact of initial consumer trust on intentions to transact with a web site: a trust building model. The Journal of Strategic Information Systems, 11, 297323. http://dx.doi.org/10.1016/S0963-8687(02)00020-3

Hsu, C. L., Chang, K. C., \& Chen, M. C. (2012). Flow experience and internet shopping behavior: Investigating the moderating effect of consumer characteristics. Systems Research and Behavioral Science, 29, 317-332. http://dx.doi.org/10.1002/sres.1101

Huizingh, E. K. (2000). The content and design of web sites: an empirical study. Information \& Management, 37, 123-134. http://dx.doi.org/10.1016/S0378-7206(99)00044-0

Hwang, Y., \& Kim, D. J. (2007). Customer self-service systems: The effects of perceived Web quality with service contents on enjoyment, anxiety, and e-trust. Decision Support Systems, 43, 746-760. http://dx.doi.org/10.1016/j.dss.2006.12.008

Jacoby, J. (2002). Stimulus-organism-response reconsidered: an evolutionary step in modeling (consumer) behavior. Journal of Consumer Psychology, 12, 51-57. http://dx.doi.org/10.1207/S15327663JCP1201_05

Jeong, S. W., Fiore, A. M., Niehm, L. S., \& Lorenz, F. O. (2009). The role of experiential value in online shopping: The impacts of product presentation on consumer responses towards an apparel web site. Internet Research, 19, 105-124. http://dx.doi.org/10.1108/10662240910927858

Karimov, F. P., Brengman, M., Van Hove, L., \& Van, L. (2011). The effect of website design dimensions on initial trust: a synthesis of the empirical literature. Journal of Electronic Commerce Research, 12, 272-301.

Kawaf, F., \& Tagg, S. (2012). Online shopping environments in fashion shopping: An SOR based review. The Marketing Review, 12, 161-180. http://dx.doi.org/10.1362/146934712X13366562572476

Kim, J., \& Larose, R. (2004). Interactive E-Commerce: Promoting Consumer Efficiency or Impulsivity? Journal of Computer-Mediated Communication, 10. 
Kim, M., \& Lennon, S. (2008). The effects of visual and verbal information on attitudes and purchase intentions in internet shopping. Psychology \& Marketing, 25, 146-178. http://dx.doi.org/10.1002/mar.20204

Kim, S., \& Lehto, X. Y. (2013). Projected and Perceived Destination Brand Personalities The Case of South Korea. Journal of Travel Research, 52, 117-130. http://dx.doi.org/10.1177/0047287512457259

Law, R., \& Cheung, C. (2006). A study of the perceived importance of the overall website quality of different classes of hotels. International Journal of Hospitality Management, 25, 525-531. http://dx.doi.org/10.1016/j.ijhm.2005.03.001

Liao, C., Palvia, P., \& Lin, H. N. (2006). The roles of habit and web site quality in e-commerce. International Journal of Information Management, 26, 469-483. http://dx.doi.org/10.1016/j.ijinfomgt.2006.09.001

Liu, C., \& Arnett, K. P. (2000). Exploring the factors associated with Web site success in the context of electronic commerce. Information \& management, 38, 23-33. http://dx.doi.org/10.1016/S03787206(00)00049-5

Louis, D., \& Lombart, C. (2010). Impact of brand personality on three major relational consequences (trust, attachment, and commitment to the brand). Journal of Product \& Brand Management, 19, 1141-30. http://dx.doi.org/10.1108/10610421011033467

Lowry, P. B., Vance, A., Moody, G., Beckman, B., \& Read, A. (2008). Explaining and predicting the impact of branding alliances and web site quality on initial consumer trust of e-commerce web sites. Journal of Management Information Systems, 24, 199-224. http://dx.doi.org/10.2753/MIS0742-1222240408

Malhotra, N. K. (2008). Marketing Research: An Applied Orientation, 5/E, Pearson Education India.

Mcknight, D. H., Kacmar, C. J., \& Choudhury, V. (2004). Dispositional trust and distrust distinctions in predicting high-and low-risk internet expert advice site perceptions. E-Service Journal, 3, 35-55. http://dx.doi.org/10.2979/ESJ.2004.3.2.35

Mehrabian, A., \& Russell, J. A. (1974). An approach to environmental psychology. The MIT Press.

Muller, B., \& Chandon, J. L. (2003). The impact of visiting a brand website on brand personality. Electronic Markets, 13, 210-221. http://dx.doi.org/10.1080/1019678032000108301

Muthitcharoen, A. M., Palvia, P. C., \& Grover, V. (2011). Building a model of technology preference: The case of channel choices. Decision Sciences, 42, 205-237. http://dx.doi.org/10.1111/j.1540-5915.2010.00306.x

Pavlou, P. A. (2003). Consumer acceptance of electronic commerce: integrating trust and risk with the technology acceptance model. International journal of electronic commerce, 7, 101-134.

Poddar, A., Donthu, N. \& Wei, Y. (2009). Web site customer orientations, Web site quality, and purchase intentions: The role of Web site personality. Journal of Business Research, 62, 441-450. http://dx.doi.org/10.1016/j.jbusres.2008.01.036

Ranganathan, C., \& Ganapathy, S. (2002). Key dimensions of business-to-consumer web sites. Information \& Management, 39, 457-465. http://dx.doi.org/10.1016/S0378-7206(01)00112-4

Rose, G., Khoo, H., \& Straub, D. W. (1999). Current technological impediments to business-to-consumer electronic commerce. Communications of the AIS, $1,1$.

Rowley, J. (2004). Online branding. Online Information Review, 28, 131-138. http://dx.doi.org/10.1108/14684520410531637

Schlosser, A. E., White, T. B., \& Lloyd, S. M. (2006). Converting web site visitors into buyers: how web site investment increases consumer trusting beliefs and online purchase intentions. Journal of Marketing, 133148. http://dx.doi.org/10.1509/jmkg.70.2.133

Sherman, E., Mathur, A., \& Smith, R. B. (1997). Store environment and consumer purchase behavior: mediating role of consumer emotions. Psychology \& Marketing, 14, 361-378. http://dx.doi.org/10.1002/(SICI)15206793(199707)14:4<361::AID-MAR4>3.0.CO;2-7

Sillence, E., Briggs, P., Harris, P., \& Fishwick, L. (2006). A framework for understanding trust factors in webbased health advice. International Journal of Human-Computer Studies, 64, 697-713. http://dx.doi.org/10.1016/j.ijhcs.2006.02.007

Sirgy, M. J. (1982). Self-concept in consumer behavior: A critical review. Journal of consumer research, 287300. http://dx.doi.org/10.1086/208924 
Van Der Heijden, H., Verhagen, T., \& Creemers, M. (2003). Understanding online purchase intentions: contributions from technology and trust perspectives. European Journal of Information Systems, 12, 41-48. http://dx.doi.org/10.1057/palgrave.ejis.3000445

Wan, H. A. (2000). Opportunities to enhance a commercial website. Information \& Management, 38, $15-21$. http://dx.doi.org/10.1016/S0378-7206(00)00048-3

Wang, Y. S., Yeh, C. H., \& Liao, Y. W. (2012). What drives purchase intention in the context of online content services? The moderating role of ethical self-efficacy for online piracy. International Journal of Information Management.

Wells, J. D., Parboteeah, V., \& Valacich, J. S. (2011). Online impulse buying: understanding the interplay between consumer impulsiveness and website quality. Journal of the Association for Information Systems, 12, 32-56.

Yoon, S. J. (2002). The antecedents and consequences of trust in online-purchase decisions. Journal of interactive marketing, 16, 47-63. http://dx.doi.org/10.1002/dir.10008

Zhang, P., \& Von Dran, G. M. (2002). User expectations and rankings of quality factors in different web site domains. International Journal of Electronic Commerce, 6, 9-34.

\section{Copyrights}

Copyright for this article is retained by the author(s), with first publication rights granted to the journal.

This is an open-access article distributed under the terms and conditions of the Creative Commons Attribution license (http://creativecommons.org/licenses/by/3.0/). 